\title{
Integrating Marine Protected Areas in fisheries management systems: some criteria for ecological efficiency
}

\author{
Lucile MESNILDREY, Didier GASCUEL and Olivier LE PAPE ${ }^{\mathrm{a}}$ \\ Université Européenne de Bretagne, AgroCampus Ouest, UMR 985 Ecologie et Santé des Ecosystèmes, 65 rue de St Brieuc, CS 84215 , \\ 35042 Rennes Cedex, France
}

Received 14 May 2012; Accepted 29 March 2013

\begin{abstract}
Through a review of the scientific literature and a more in-depth qualitative meta-analysis of 16 case studies distributed worldwide, this article aims to study impacts of MPAs on marine living resources, ecosystems and related fisheries and to highlight their criteria of efficiency as management tools for a sustainable exploitation. MPAs are efficient for conservation purposes and resource restoration, especially inside their borders. MPAs can also be part of fisheries management systems, but there is a lack of knowledge about their wider scale impacts on fish stocks, ecosystem and fisheries. Adjacent fisheries can increase their catches near closed areas, but such effects are delayed until after MPA establishment and are often limited over distance. Even though local specificities in ecosystems and fishing resources lead to high variability in MPA effects, four major criteria modulate the efficiency of MPAs for fisheries management: (1) the size of the closed area; (2) the level of protection of essential habitats for exploited resources; (3) MPA integration as part of wider integrated fisheries management plans; and (4) efficient monitoring and regulation systems, including participative decision making, to ensure that restrictive measures are respected.
\end{abstract}

Keywords: Marine Protected Areas (MPAs) / Fishing reserve effects / Fisheries management / Marine reserve network

\section{Introduction}

For decades, numerous management systems have been designed to control the effects of fishing activities on marine resources but also to ensure the sustainability of exploitation and fishermens' activities. Management measures have evolved over years to take into account new knowledge acquired on species biology and marine ecosystem dynamics, but also the efficiency of fisheries management measures and governance strategy. Until the present decade, systems of management were usually based on single species approaches and were often insufficient to manage all fishing activities and reach the objectives of marine ecosystem conservation and economic profitability of fisheries (Pauly et al. 2003; MEA 2005; FAO 2009). It is now considered necessary to integrate single species management into an ecosystem approach to take into account other species (including non-commercial species), interactions between species, habitats, other sources of disturbances and global change (Garcia and Cochrane 2005; Worm et al. 2009: Jennings and Rice 2011).

At the World Summit on Sustainable Development (2002) the recommended approach was to consider the whole ecosystem and to take into account all natural and anthropogenic pressures in an integrated management strategy (FAO 2003). If

\footnotetext{
a Corresponding author:

olivier.lepape@agrocampus-ouest.fr
}

measures of stock regulation remained necessary, in particular to reach the objective of returning to the Maximum Sustainable Yield in 2015, it was agreed to develop the use of complementary methods to manage ecosystems, in particular by the creation of marine protected areas (MPAs).

In MPAs, all or some extractive activities involving marine resources are forbidden, permanently or seasonally, to protect the enclosed environment (Kelleher 1999). Some MPAs are no-take zones (fishing and other activities are forbidden) while others allow a range of uses managed by zoning and/or time limitation of access. All kinds of human pressures (professional fishing, sailing, diving, extraction of sediments, destruction of habitats and introduction of species) can be regulated. MPAs can have two main objectives. On the one hand, MPAs could ensure the preservation of biodiversity, the conservation of sensitive species and the protection of habitats. On the other hand, they could contribute to the limitation of fishing pressure on fish populations and ecosystems and be part of the management system (Rice et al. 2012; Roberts et al. 2012).

Nevertheless, controversial points of view remain about the effectiveness of MPAs as an efficient management tool for sustainable fisheries (Hilborn et al. 2004; Kaplan 2009; Kearney and Farebrother 2012). Through a review and a complementary qualitative meta-analysis based on 16 documented case studies of MPAs distributed worldwide, the aim of the present paper is to study the impacts of MPAs on living 


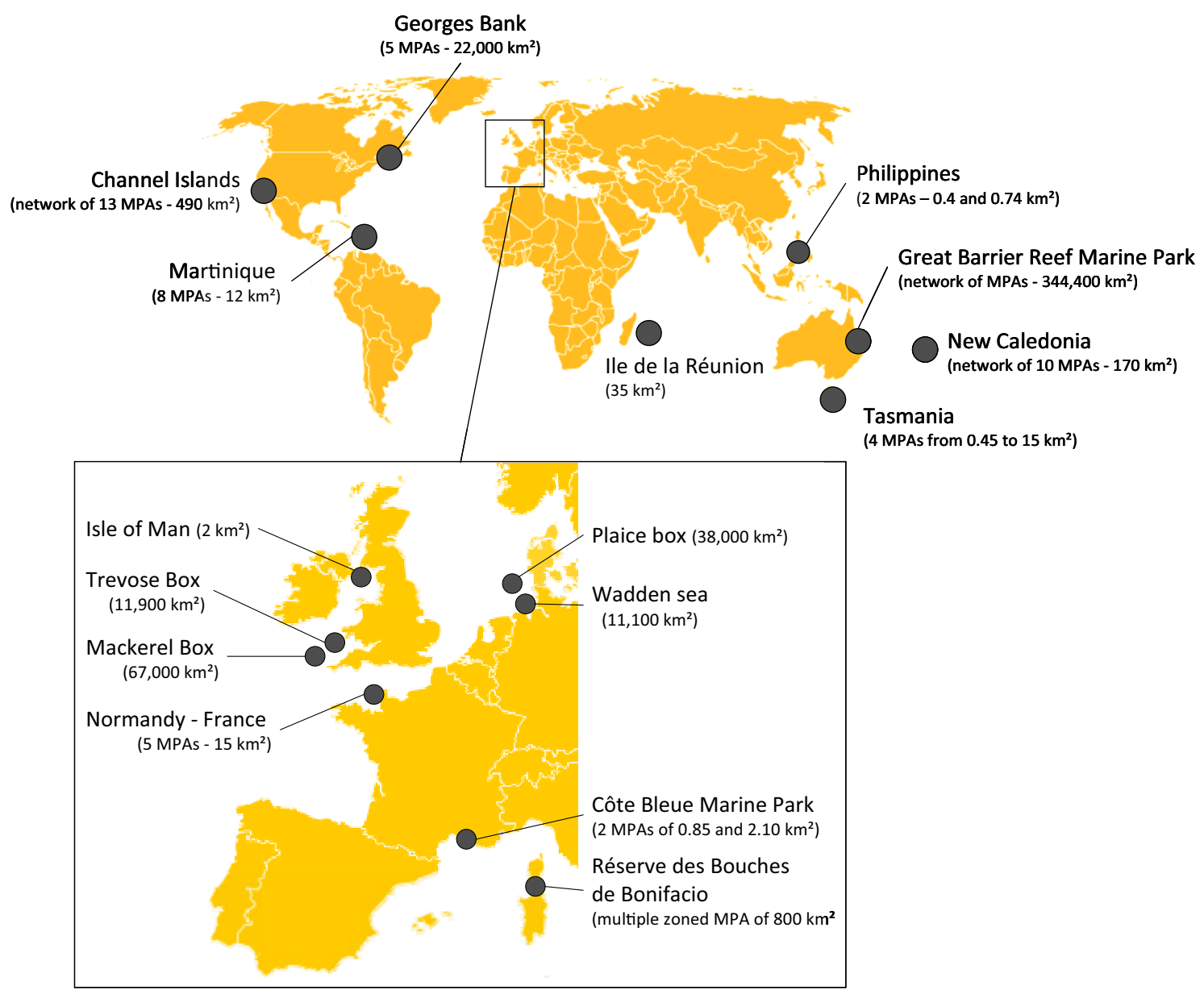

Fig. 1. Overall location of the case studies selected in the analysis.

resources, ecosystems and fisheries, to examine the current state of knowledge and to identify criteria of ecological efficiency to use as management tools for sustainable exploitation.

\section{Ecological effects of fishing reserves and consequences for fisheries}

The present analysis is based on a review of the scientific literature and a more in-depth qualitative meta-analysis of case studies. Sixteen well documented MPAs were selected in order to cover a variety of characteristics in terms of size, depth, seafloor and objectives pursued (Fig. 1). Scientific monitoring of no-take zones, when access restrictions are respected, appears relatively easy to analyse: if all activities are prohibited, it seems possible to know whether the observed effects are due to a reserve effect. In multiple-use MPAs where activities such as fishing are authorized, the observed effects are more difficult to estimate. It is indeed difficult to estimate the consequences of the residual fishing activities on mitigating the effect of spatial protection. No-take zones were thus overrepresented in the selected case studies.

Both the conclusions drafted from the case studies and those found in the literature allowed qualitative estimates to be made of the ecological benefits of fishing reserves inside and outside their limits and of the consequences for fisheries outside no-take zones (Table 1).

\subsection{Impacts on marine resources and ecosystems}

\subsubsection{Positive effects on fish populations and ecosystems inside fishing reserves}

Banning fishing activities in an area allows protected communities to reconstitute themselves inside this area, especially if the previous fishing pressure was strong. The abundance, mean size and, therefore, biomass of fish increase, but so does the biodiversity (Worm et al. 2006; Lester et al. 2009). In particular, the densities of large, older fish, which would have been captured if fishing had been maintained, increase significantly (Gell and Roberts 2003; Halpern 2003). Accordingly, predator species, which are often those most impacted by fisheries, benefit highly from local fisheries restrictions. These conclusions are especially visible (Tetreault and Ambrose 2007; Claudet et al. 2008; Colléter et al. 2012) on target species for fisheries, e.g., in the Channel Islands marine reserves and California (Hamilton et al. 2010) and in the Great Barrier Reef; (Russ et al. 2008).

Stopping fishing inside reserves could also lead to trophic cascade, increased predation (Fanshawe et al. 2003; 
Table 1. In MPAs, different types of zones may accommodate multiple and often conflicting objectives. Scores are used to integrate multiple objectives and identify different zoning configurations or explored priority areas for each zone separately.

\begin{tabular}{|c|c|c|c|c|c|c|}
\hline \multirow[b]{2}{*}{$\begin{array}{l}\text { Marine protected } \\
\text { areas }\end{array}$} & \multirow[b]{2}{*}{$\begin{array}{l}\text { Surface } \\
\left(\mathrm{km}^{2}\right)\end{array}$} & \multirow[b]{2}{*}{$\begin{array}{l}\text { Access } \\
\text { regulation }\end{array}$} & \multicolumn{2}{|c|}{ Ecological effects } & \multirow[b]{2}{*}{$\begin{array}{l}\text { Impacts } \\
\text { on fisheries }\end{array}$} & \multirow[b]{2}{*}{ References } \\
\hline & & & Inside & Outside & & \\
\hline Great Barrier Reef & 344400 & $\begin{array}{c}\text { Multiple } \\
\text { Zoned MPAs }\end{array}$ & + & + & - & $\begin{array}{l}\text { Ayling and Choat 2008; Little et al. 2009; } \\
\text { McCook et al. 2010; Russ et al. 2008; } \\
\text { http://www.gbrmpa.gov.au/corp_site } \\
\text { /management/zoning/comercial_fishing. }\end{array}$ \\
\hline Mackerel Box & 67000 & Partial access & + & + & + & Sweeting and Polunin 2005; Uriarte et al. 2001. \\
\hline Plaice box & 38000 & Partial access & - & 0 & 0 & $\begin{array}{l}\text { Beare et al. 2010; Grift et al. 2004; } \\
\text { Pastoors et al. 2000. }\end{array}$ \\
\hline Georges bank & 17000 & No-take zone & + & + & + & $\begin{array}{l}\text { Fogarty and Murawski 1998; Gell and Roberts 2002; } \\
\text { Hart and Rago 2006; Holland 2000; } \\
\text { Murawski et al. 2000; Murawski et al. 2005; } \\
\text { Tian et al. 2009. }\end{array}$ \\
\hline Trevose box & 11900 & Partial access & + & + & - & ICES 2007. \\
\hline Wadden sea & 11100 & $\begin{array}{c}\text { Multiple } \\
\text { Zoned MPAs }\end{array}$ & + & 0 & - & $\begin{array}{l}\text { Imeson and Van Den Bergh 2006;Verhulst et al. 2004; } \\
\text { http://www.waddensea-secretariat.org/ } \\
\text { trilat/brochure/brochure.html. }\end{array}$ \\
\hline $\begin{array}{l}\text { Bouches de } \\
\text { Bonifacio }\end{array}$ & 800 & $\begin{array}{c}\text { Multiple } \\
\text { Zoned MPAs }\end{array}$ & + & 0 & + & Albouy et al. 2010; Planes et al. 2008. \\
\hline Channel Islands & 490 & No-take zone & + & 0 & - & $\begin{array}{l}\text { Behrens and Lafferty 2004; Hamilton et al. 2009; } \\
\text { http://www.dfg.ca.gov/marine/ } \\
\text { channel_islands/specialsession.asp. }\end{array}$ \\
\hline New Caledonia & 100 & $\begin{array}{c}\text { Multiple } \\
\text { Zoned MPAs }\end{array}$ & + & 0 & 0 & $\begin{array}{l}\text { Chateau and Wantiez 2005; Chateau and Wantiez 2009; } \\
\text { David et al. 2010; Ferraris et al. 2005; } \\
\text { Guillemot et al. 2009; Jollit et al. 2010; } \\
\text { Preuss et al. 2009; Wantiez et al. } 1997 \text {. }\end{array}$ \\
\hline Réunion & 35 & $\begin{array}{c}\text { Multiple } \\
\text { Zoned MPAs }\end{array}$ & 0 & 0 & + & $\begin{array}{l}\text { Pers. comm. from } \\
\text { fishers organisation }\end{array}$ \\
\hline Tasmania & 0.5 to 15 & No-take zone & $+/-$ & 0 & + & $\begin{array}{l}\text { Barrett et al. 2007; Barrett et al. 2009; } \\
\text { Edgar et al. 2004; Edgar and Barrett } 1999 .\end{array}$ \\
\hline Normandy & 1.3 to 7.8 & No-take zone & + & 0 & + & $\begin{array}{l}\text { Pers. comm. } \\
\text { from fishers organisation }\end{array}$ \\
\hline Martinique & 1.1 to 11.6 & No-take zone & 0 & 0 & 0 & $\begin{array}{l}\text { Criquet et al. 2008; pers. comm. } \\
\text { from fishers organisation }\end{array}$ \\
\hline Isle of Man & 2 & No-take zone & + & + & + & $\begin{array}{l}\text { Beukers-Stewart et al. 2003; Beukers-Stewart et al. 2005; } \\
\text { Sweeting and Polunin } 2005 \text {. }\end{array}$ \\
\hline $\begin{array}{l}\text { Côte Bleue } \\
\text { Marine Park }\end{array}$ & 0.85 and 2.10 & No-take zone & + & 0 & + & $\begin{array}{l}\text { Forcada et al. 2009; Harmelin-Vivien et al. 2008; } \\
\text { http://www.parcmarincotebleue.fr/page\%20etudes/ } \\
\text { Etudes.html. }\end{array}$ \\
\hline Philippines & 0.40 and 0.74 & No-take zone & + & 0 & + & $\begin{array}{l}\text { Alcala et al. 2005; Alcala and Russ 2006; } \\
\text { Russ et al. 2003; Russ and Alcala } 1996 .\end{array}$ \\
\hline
\end{tabular}


Guidetti 2006; Saintilan et al. 2008), and unforeseen changes in the structure of communities rather than to the reconstruction of targeted populations. In some Tasmanian fishing reserves, where lobsters and abalones were previously subjected to high fishing pressure, the abundance of abalones decreased by half in ten years of protection while it remained stable in the exploited areas. This decrease is supposed to be related to the intensification of predation on young abalone due to an increase of predation by lobsters (Barrett et al. 2009). On the contrary, trophic cascades can lead to positive effects, such as the reduced spread of harmful macroalgae in coral reef ecosystems though the increased biomass of their natural grazers (Shears and Babcock 2003; Shears et al. 2008).

\subsubsection{Positive effects on fish populations and ecosystems outside fishing reserves}

Once the protected fraction is reconstituted, if individuals are mobile, then these fish can move outside of the closed area. This is "spillover effect". The magnitude of the spillover (increasing the range of abundance and spatial extent of density enhancement) depends partially on fish characteristics. For sedentary species, movements of adults and juveniles can be limited or even non-existent. In contrast, more mobile species should be able to benefit from spillover effect (e.g., in Carryle-Rouet (Mediterranean coast, France) Harmelin-Vivien et al. 2008) if a sufficient part of their life cycle is protected by the fishing reserve (Maury and Gascuel 1999; Moffitt et al. 2009; Grüss et al. 2011a). Based on food web models, and not taking into account fishing reserves effects on habitats, some studies have shown that potential exports of biomass are of the same order of magnitude as what could have been caught inside the reserve without any protection (Valls et al. 2012; Brochier et al. 2013). However, only a few in situ studies focusing on mobile species support this argument.

Besides the movements of young and adults out of the reserve, we should also consider other positive ecological effects of fishing reserves outside their limits. Spawning biomass increases inside fishing reserves and potential amount of spawning products is also enhanced by increasing density of old fertile individuals (Berkeley et al. 2004). The related quantity of eggs and larvae produced in reserves can dramatically increase after closure, particularly if past exploitation has sharply reduced spawning biomass. Therefore eggs and $\backslash$ or larvae produced inside the reserve can spread towards the open areas and enhance the fish population (Harrison et al. 2012). This disseminating effect strongly depends on both local hydrodynamics and the life history of the species concerned. For instance, the study conducted in the George bank fishing reserves showed that in some closed areas, $86 \%$ of larvae were retained within the closed areas whereas in other reserves a large part of the emitted larvae was spread outside (Murawski et al. 2000; Tian et al. 2009). A significant increase of the adult biomass directly related to larval enhancement from a reserve was observed up to $8 \mathrm{~km}$ from a closed area for abalone in California (Sweeting and Polunin 2005). More generally, Moffit et al. (2009) estimated that larval dissemination could have a greater influence than fish spillover among positive effects of MPAs outside their limits.

\subsection{Impacts on fisheries}

Impacts of fishing reserves on fisheries have been less studied than their ecological consequences. Some general insights can nevertheless be addressed from both literature and case studies. Indeed, closing areas to fishing could be compared to a reduction of fishing mortality in traditional fisheries management (Maury and Gascuel 1999; Hart 2006):

\subsubsection{Immediate negative consequences on fisheries}

At first, the establishment of a fishing reserve leads to a reduction of catches in the short term. The scale of this loss varies according to the previous importance of the zone for fisheries but also to the level of access limitation (Holland 2000; Boncoeur 2004).

The redistribution of fishing effort towards other zones and $\backslash$ or other fisheries can lead to an increase in the costs for the fishermen who have to move to new areas or change equipment. It can also provoke a congestion of zones remaining opened to fishing, and an increase in conflicts and pressure on the resource (Holland 2000; Sanchirico et al. 2002; Boncoeur 2004). For instance, in the George bank area, only four years after the implementation of closed areas, the spatial redistribution of fishing effort towards other zones caused a severe decline of the cod stocks in the bay of Maine (Holland 2000). The redistribution of fishing effort is sometimes impossible because lack of quotas of capture or access allowance are unavailable or because operational costs increase. In that case, fishing boats have to sharply reduce or even stop their activity.

\subsubsection{Positive consequences at mid-term, related to ecological effects of MPAs}

Fishing reserves can contribute to reducing fishing mortality on exploited populations and be part of fisheries management. This is the case when fishing reserves cover areas where high densities of exploited species are observed, as fishermen do not have the opportunity to relocate outside the closed area the whole fishing effort applied inside prior to the implementation of fishing restrictions (Maury and Gascuel 1999; Hart 2006). However, only a few studies have been carried out on the effects of fishing reserves on the scale of fish stocks and fisheries, which is a major limitation to estimating their effects at a relevant scale for the management of fish resources (Grüss et al. 2011a).

Among our case studies, the Trevose box demonstrates that such effects can be significantly positive. This box was established on a cod spawning area to reduce fishing mortality of the stock. A displacement of the fishing activities outside of the spawning area was observed, but the decrease induced in the fishing mortality of the cod stock reached 13\% (ICES 2007).

When population renewal is enhanced by a reduction in fishing mortality, increased yields are expected for fisheries. This process has been demonstrated from previous metaanalysis (Worm et al. 2006). Nevertheless, benefits for fisheries are often localized near the reserve. In theory, when the fishing effort is high, fishing reserves should contribute to improving 
captures near their borders, thus counterbalancing the negative impact due to the decrease of the initial fishing zone. In practice, this effect is shown by the concentration of fishing boats near fishing reserve borders (i.e., fishing the line; Grüss et al. 2011a; 2011b). In relation to this "fishing the line" effect, in several case studies (e.g., Murawski et al. 2005), the biomass of fishes has been shown to decrease strongly on the borders of closed areas.

Another potential positive effect of fishing reserves for fisheries is related to their positive influence on the stability of fishing resources (Pitchford et al. 2007) and ecosystems (Ling and Johnson 2012). With more extended size and age structure and a part of the population protected from fishing-induced evolution (Roberts et al. 2005), fish populations are more resilient to the combined effects of environment fluctuations and fishing pressure (Gell and Roberts 2002), have less recruitment fluctuation, faster reconstitution (Roberts and Hawkins 2000 and 2012) and face a lower risk of collapse (Perez Ruzafa et al. 2006).

From this short overview of the potential fishing reserve effects on resources for fisheries, positive effects can be expected in terms of sustainability for fisheries: the protection of habitats with a specific interest for exploited resources, the protection of highly productive areas able to provide significant spillover effects or larval dispersion and the reduction in overall fishing mortality. From a previous worldwide metaanalysis, Worm et al. (2006) reported an increase in fishing yields related to the positive effects of fishing reserves. Nevertheless, existing MPAs (i) aim at protecting highly variable resources under combined environmental (e.g., climatic) and anthropogenic pressures; (ii) are not randomly located and can protect specific habitats and hotspots; (iii) are far from being only no-take zones (although effects are more easy to measure in this case). It is thus complicated to distinguish the effects due to the fishing reserve from the variability linked to changes in the environmental conditions or even in reserve or fisheries management.

\section{Criteria of efficiency of marine reserves}

The analysis of the scientific literature and qualitative meta-analysis on case studies highlight that fishing reserve effects are not systematic and depend on several criteria. In particular, the effects of fishing reserves outside their borders face major sources of variability and uncertainty and depend on connectivity between closed areas and neighbouring zones (i.e., numerous criteria such as larval dispersal, movement of individuals including seasonal migrations, and fishing pressure on the reserve borders, Grüss et al. 2011a; 2011b). The ecological and fishing benefits of marine reserves vary according to species, their degree of exploitation and the characteristics of the reserves. In the following section, we highlight the main criteria to be taken into account to ensure fishing reserve efficiency for living resources, ecosystems and fisheries.

\subsection{Time of response after closure}

The effects of fishing reserves inside their borders are generally observed after several years of protection
(Claudet et al. 2008; Vandeperre et al. 2010). The time taken to observe a reserve effect depends on numerous criteria. This time can vary according to biological characteristics of species (spawning biomass, age at maturity, growth rate, fertility, lifecycle, etc.). Some species, such as scallops, grow fast, can reproduce at a young age and produce a large number of eggs. Thus, these animals become rapidly much more abundant, in only one or two years of protection (Anonymous 2007). For instance, in the Georges Bank fishing reserves after five years of protection, scallop biomass (Placopecten magellanicus) increased 14-fold within the closed areas (Murawski et al. 2000), and eleven years after the establishment of the fishing reserves, this increase reached 25-fold (Hart and Rago 2006). On the contrary, other species, such as predatory fishes, grow slowly and reproduce later, meaning that their increase in the reserve occurs many years after its establishment (Anonymous 2007). The response time after a reserve is established also depends on interactions between species (predators-prey relations and cascade effect) (Shears and Babcock 2003; Barrett et al. 2009) and on habitats restoration, i.e., complex and long, often decadal, processes (Lester et al. 2009; Worm et al. 2006). Exploited species often answer more rapidly to the protection while non-exploited species do not benefit in the same way (Chateau and Wantiez 2005). Nevertheless, the beneficial effects on fisheries are generally delayed. Indeed, they can be observed only when the resources and/or the levels of reproduction in the reserve allow a reseeding of the neighbouring zones.

From this point of view, there is a need to maintain access restriction on the long term. Indeed, reopening of protected areas provokes a concentration of fishing effort, a fast decrease in the biomass and a dispersal of individuals outside the formerly protected zones. This is what happened in the reserve of Sumilon (in the Philippines) where protection was stopped twice for political reasons. During the first reopening of the reserve, the biomass of fishes declined by $43 \%$ in two years. This area was then closed for 9 years allowing the biomass to increase by $60 \%$. But a second reopening led to a decline of about $66 \%$ of the biomass in one year (Alcala et al. 2005).

In other words, fishing reserve effects in terms of fisheries management can be observed after relatively short or medium term fishing restrictions when they are related to a reduction in fishing mortality. In contrast, when benefits depend on the restoration of habitats and/or ecosystem structure, the time response is longer (usually decades). Restrictions have to be maintained, as both short and long term effects could be eliminated if fishing access restrictions are removed, even for a short period of reopening.

\subsection{Influence of the size of fishing reserves}

\subsubsection{Inside a fishing reserve}

Meta-analysis (Lester et al. 2009; Halpern 2003) demonstrated that biological effects observed in response to protection (biomass, density, size of the individuals, biodiversity, habitat and trophic structure) inside fishing reserves were observed independently from the size of the reserves. Fishing reserves have positive effects on protected communities, even 


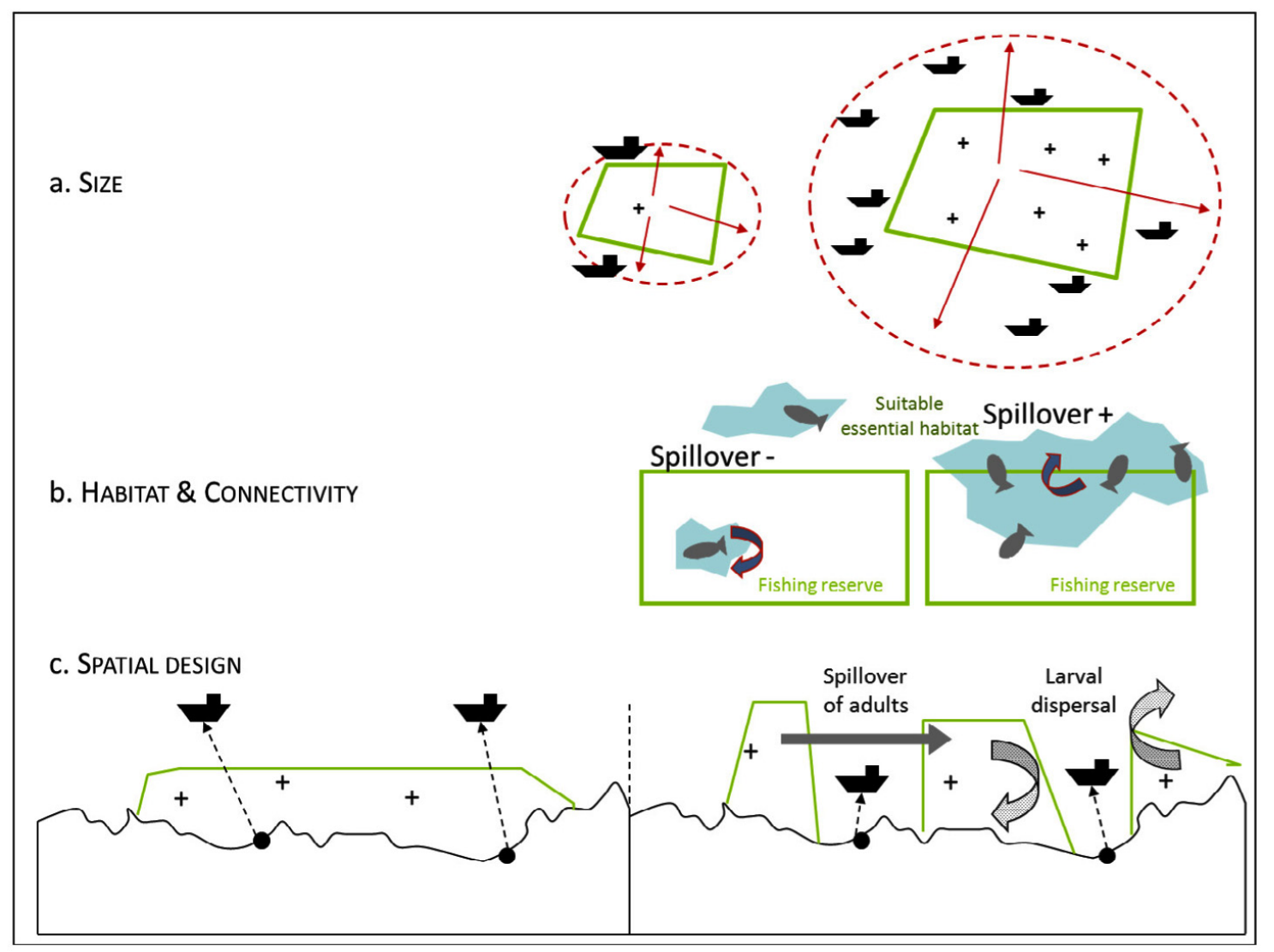

Fig. 2. Factors influencing MPA effectiveness.

when they are small (Fig. 2a). Accordingly, the present case study analysis presented quite systematic positive effects of area closure for living resources (Table 1).

Nevertheless, the scale of these impacts is greater if a reserve is larger (Halpern 2003) (Fig. 2a). To be efficient for the preservation of ecosystems and biodiversity, reserves have to cover a sufficient surface area. The larger a fishing reserve, the better the protection of living resources (Sale et al. 2005). Species diversity also increases with the surface area of fishing reserves (Neigel 2003). The larger the protected area is, the stronger the increase in density of exploited species (Claudet et al. 2008). Furthermore, a large reserve could protect all habitats that an individual uses during its life (in the case of nonmigratory species) (Sale et al. 2005). Large reserves can also hold more eggs, larvae and $\backslash$ or young within their borders, allowing a stronger reseeding of the protected populations.

\subsubsection{Outside the limits of a fishing reserve}

If the objective of a reserve is to manage one or several fish stocks of commercial interest, it is important to know on what spatial scale fisheries can benefit from the decline of fishing mortality, as well as larval dispersion and spillover effect (Hart 2006). While fishing reserves must be large enough to contain and protect a population of adequate size, they also have to increase the production of species fished outside (Hart 2006; Sale et al. 2005). For example, for the cod from Georges Bank area, a migratory species intensely fished in the $80 \mathrm{~s}$, a modelling approach estimated that the collapse of the stock in 1992 would have been avoided if $80 \%$ of the zone had been closed to fishing activities (without additional measures of management). The reconstruction of the stock would also have been possible, with reserves of moderate size (20\%) and if seasonal closures had been put in place (Guénette et al. 2000). Sale et al. (2005) consider that establishing no-take zones representing approximately $20 \%$ of fishing zones would generally allow the objectives of preservation of marine biodiversity and sustainable management of exploited stocks to be achieved.

The size of fishing reserves, mobility of the resources, and their demographic characteristics interact and influence the effects of reserves on fisheries (Hart 2006). The present analysis of case studies based on in situ observations leads to us to conclude that the positive effect of fishing reserves on living resources outside their limits is more frequently seen with large reserves (Table 1). Moreover, Forcada et al. (2009) stated that if a reserve is small in size, its influence on the adjacent zones will be limited. Accordingly, the present analysis showed a relative proportionality between the spatial scale of the border effect and the surface of the marine reserve: the bigger the marine reserves, the stronger and the more extended the border effect (Fig. 2a).

Nevertheless, the influence of the size of the no-take area on surrounding fisheries appears delayed and complex (Vandeperre et al. 2010). Overall catch rates appeared to increase close to small no-take areas. When no-take areas were larger, catches only increased in the fisheries that were 
expected to benefit most from protection. Accordingly, the present meta-analysis underlines the same patterns. While small MPAs seem to positively affect fisheries, some larger ones are considered to produce negative overall consequences (Table 1). Nevertheless, these conclusions were drawn from a variety of case studies, often based on the qualitative perception of local fishermen, and do not provide reliable information about consequences of MPAs at the scale of exploited populations and ecosystems. Even though some modelling approaches have focused on this question (Hart 2006; Grüss 2011b), such large scale information is rarely available from in situ data.

\subsection{Spatial design and organization of access restrictions in fishing reserve networks}

\subsubsection{Identifying essential fish habitats to optimize Marine Protected Area design}

Obviously, MPA networks are especially effective when every kind of habitat essential to the completion of fish life cycles is represented. To protect both adults and juveniles of mobile species facing ontogenetic changes in their spatial distribution, reserves need to be very large (Grüss 2011a). Nevertheless, to optimize their size-related efficiency, marine reserves could have the objective to protect essential habitats for the realization of a stage of development (spawning areas, nurseries, etc.) (Gell and Roberts 2003; Nagelkerten et al. 2012).

In certain cases, banning fishing activities in spawning areas to limit fishing mortality protects large individuals, which are old and fertile, and thus enhances spawning biomass leading to an improvement in recruitment (Grüss 2011a). This is the case in the Trevose Box, for instance, whose objective is to decrease the fishing mortality of the spawning stock of Celtic sea cod.

In other situations, the protection of juveniles is more effective for ensuring the sustainability of a stock. For example, for saithe in western Scotland, overexploited during the 1990s, banning access to areas of distribution of the juveniles would have been more effective in terms of biomasses than sharply decreasing overall fishing mortalities, with far fewer negative consequences for catches and fisheries (Pelletier and Magal 1996).

The consideration of the life cycle of resources to be protected and their dependence on specific habitats is an essential component for defining effective zones of protection. Indeed, if the distribution of habitats inside and in the proximity of the protected sites is inadequate, the expected effects from a reserve, particularly spillover, can be strongly decreased (Forcada et al. 2009). So that a species benefits totally from the protection, a reserve network has to include the habitats essential for it to accomplish its life cycle (Van de Wolsfaar et al. 2011) and these must be sufficiently connected via animal movements (Blowes and Connoly 2012) (Fig. 2b).

\subsubsection{The single large or several small (SLOSS) controversy}

In many regions, biogeographical or socioeconomic reasons make it impossible to have a single rather large fishing reserve to protect all habitats and the implementation of several small MPAs has been considered as a solution.

Fishing reserve size and distance between the reserves have to take into account the larval dispersal of species to be protected (Shanks et al. 2003). If a single reserve is not large enough, an important proportion of larvae becomes dispersed outside the reserve and does not ensure the reseeding of the protected population. A network of several medium-sized reserves instead allows production of larvae, which will be dispersed towards the other reserves or ensure the improvement of the recruitment in protected zones (Bergen and Carr 2003).

MPA network projects often result more from human criteria than from ecological reasons, i.e., the preservation of small fisheries and/or leisure activities, minimization of conflicts between users or opportunities for effective control. For example, a large fishing reserve obliges local fishermen to increase both their travel time to reach new areas and their production costs. For practical purposes, the creation of several small reserves is often the only option possible along an urbanized coast where the marine environment is exploited by a multitude of different users (Francour et al. 2001; Anonyme 2007). One of the major socioeconomic advantages of marine reserve networks compared with a single large reserve is the possibility to fish between the reserves rather than of being excluded from a wide zone (Fig. 2c).

MPA networks also constitute an insurance against variations in environmental conditions, extreme climate-related events and other disasters (particularly oil spills). During a disaster affecting a zone that includes some but not all of the reserves of a network, those that are saved can allow the renewal of the affected sectors. Thus a reserve network must consider a balance between distances near enough to maintain connectivity but far enough to benefit from risk spreading (Blowes and Connoly 2012).

\subsection{Integrating fishing reserves in larger MPAs and wider fisheries management systems}

\subsubsection{Degree of protection inside MPAs}

There is a high diversity of protection rules in MPAs. Whether it is a no-take zone, a multiple-use area, and whether it is permanent or seasonal, a reserve can be effective for the preservation and the management of fisheries.

MPAs do not need to be no-take zones to reach some of their objectives. For example, when the main objective is to protect habitats, banning only dredging and trawls can be a solution less constraining than stopping all types of fishing activity. If the objective is to protect a particular species, it can be better to restrict access to certain fishing gears. Spatial management of marine resources can also be achieved through seasonal closures, in places where marine populations are particularly vulnerable during a specific life stage (in particular in spawning areas, Grüss 2011a, 2011b). This is the case of the Trevose box, where the main objective is to protect a spawning area. During three months, in the middle of the spawning season, access to this zone is forbidden for a part of the fishing boats targeting cod. Adapted supervision is required during the 
reopening for fishing activities to avoid losing the profit related to the closure.

On another level, MPAs are often organized in several zones, with a central part where all the human activities are forbidden (with the exception of controls and studies). The size of this zone of strengthened protection is usually restricted. This no-take zone is surrounded by an intermediate zone, or buffer zone, where only certain activities are subjected to limitation. Professional fishing is often authorized in the buffer zone but strictly regulated. Outside this area, the reserve then has a third zone where regulation of activities is less restrictive. This kind of organization is effective for fish resources but also for fisheries. Marine resources often benefit from partial protection in buffer zones where certain fisheries are authorized, which allows an increase of captures. In contrast, the absence of a buffer zone in which fishing would be regulated, leads to a very strong fishing pressure on the borders (Murawski et al. 2005; Harmelin-Vivien et al. 2008) with harmful effects that lower MPA benefits. A high concentration of fishers on reserve boundaries ('fishing-the-line') has the potential to significantly reduce protected population size and, later, to alter the capacity of reserves to replenish adjacent fished waters through larval, adult and juvenile export. The intensity and the scale of the spillover effect depend on the presence of such a zone of transition (Kaplan 2006; Grüss 2011b).

Restrictive measures of access must thus be chosen according to the objectives of the marine reserve. Objectives of biodiversity conservation can usually justify high restrictions, including the total ban of human activities. In contrast, objectives related to fish stocks and fisheries management do not necessarily require total closure.

\subsubsection{Integration into a management system}

To reach ecological objectives and guarantee the sustainability of fishing activities, the establishment of a fishing reserve must be integrated with other management measures. Indeed, fishing reserves are much more effective for resources and fishing activities if they are associated with additional management measures (Guénette et al. 2000).

The spatial redistribution of fishing effort that can occur when a fishing zone is closed can have harmful effects. In many cases, establishing a fishing reserve without implementation of management of the redeployment of fishing effort would not lead to positive outcomes (Hannesson 1998; Hilborn et al. 2004; Grüss 2011b). On the contrary, in the context of long term management plans, fishing reserves can contribute to limiting fishing pressure on certain stocks. For instance, the improvement of the state of the stocks in the Georges Bank area is not only linked to the implementation of closed areas. When the closed areas were established in 1994, a set of additional measures was introduced. The objectives were to limit the number of licenses for demersal fisheries, increase the size at capture and reduce the fishing effort. This combination of conventional management measures and large fishing reserves was shown to be effective for marine resources (Gell and Roberts 2002). The interest of integrating MPAs in wider fisheries management systems is widely established
(Hilborn et al. 2004; Kaplan 2009; Kearney and Farebrother 2012; Guidetti et al., 2013).

In addition, MPAs allow protection of spatial portions of the exploited marine ecosystems, not only from excessive fishing pressures but also from other anthropogenic pressures; they allow regulation or even prohibition of all activities that can potentially be harmful for marine resources and ecosystems and their exploitation. As a consequence, from the perspective of an ecosystem approach, MPAs bridge the gap between fisheries management and integrated management of marine socio-ecosystems (Guidetti et al., 2013).

\subsection{Monitoring and controling fishing reserves}

For many fishing reserves, there is lack of scientific monitoring to determine their impacts, especially on fisheries. This is the reason why the present meta-analysis was mainly based on qualitative information (Table 1). Without specific analysis, the capacity to detect and to measure the impacts of MPAs on marine resources is hindered by spatiotemporal variability of fishing resources and cannot be dissociated from other effects such as the combined ones of changes in fishing practice and additional measures of management. To analyse marine reserve effects with regard to their expected objectives, there is a need to record the initial state of fishing resources and fisheries before the establishment of the reserve. Ideally, analyses should be made before and after the implementation of the reserve on similar habitats inside and outside of the reserve (BACI: Before/After Control Impact; Saintilan et al. 2008). Such analyses, replicated in space and in time, allow the effect of a reserve to be measured. As such an analysis of the initial state is rarely made, the effects are instead considered mostly on the basis of comparisons between the inside and outside of a reserve, and thus integrate any confounding factors (e.g., previously existing gradients linked to habitat suitability and function), making the evaluation less reliable.

When one of the objectives of a reserve is to contribute to fisheries management, it is important to analyse the influence of the reserve at the scale of fish populations and fisheries (Grüss 2011a). Nevertheless, this analysis is far from systematic and consists mostly in estimating the CPUE near a reserve's borders. Monitoring has to consider reserve's impacts on the evolution of fishing activity (number of boats, fishermen) and the consequences of the transfer of fishing effort towards zones remaining open to fisheries. When stakeholders are involved in the establishment and governance of MPAs, they could helpfully contribute to monitoring systems by providing knowledge (Scholz et al. 2004) and reliable information related to resources (Edgar and Stuart Smith 2008) or fishing yields and exploitation. Often, spatial measures of management come from fishermen who notice declines of yields and worry about the sustainability of their activity.

Fishing reserve efficiency depends on the respect for the legislation. When the cooperation or the control measures are insufficient, non-compliance with fishing limitations strongly limits profits expected from the reserves (Sethi and Hilborn 2008). To guarantee the efficiency in the implementation of fishing reserves, the definition of their objectives and the enforcement of a monitoring and controlling system must 
be decided in cooperation with stakeholders, particularly fishermen. The involvement of stakeholders in decision-making is essential for the success of a marine reserve and helps to ensure respect for access restrictions (McCook et al. 2010). Fishermen are often the first to ask for effective control measures in MPAs and also outside their limits. When the establishment of an MPA is made with the cooperation of the fishermen, costs of maintining limits of access could be significantly lower. It is important to note that this cooperation is generally the rule for fishing reserves and is the reason why they are generally viewed positively by fishermen, at least after MPAs implementation, even when they were strongly opposed before these were set up. In particular, some fishermen's representatives involved in the case studies presented in Table 1 clearly defend "their" MPAs.

\section{Conclusion}

Marine protected areas were initially viewed and developed mostly as tools for biodiversity conservation. Nowadays, an increasing number of studies demonstrate that they can also be efficient tools in the context of managing marine resources and fisheries. From our review it can be highlighted that MPAs may have positive effects on fish stock abundance, recruitment and age structure, thus contributing to fisheries resources and productivity, stability and resilience. Four main processes explain the potential benefits of MPAs for fisheries: (1) spillover of fishable biomass outside of the reserve, (2) larvae dispersal from highly productive areas, (3) protection of essential habitats (spawning and nurseries grounds) and (4) reduction in overall fishing mortality in case of overexploited stocks.

Nevertheless, these beneficial effects for fisheries are far from systematic. On the one hand, fishery closure usually results in short term losses in catch and an increase in costs associated with fishing activities. On the other hand, trophic cascade and complex relationships between species could lead to unexpected results. More generally, the spatiotemporal natural variability in environmental conditions and other human impacts may conceal or compromise MPAs effect on exploited resources. Long term benefits for fishermen are generally delayed or difficult to identify and even more difficult to quantify.

There are, therefore, no standard key rules that can guarantee the ecological efficiency of MPAs in sustaining living resources and related fisheries, but some major criteria can be identified that contribute to making MPAs efficient tools for fisheries management purposes:

- Because exploited stocks are usually distributed over large areas, fisheries-oriented MPAs should generally cover large zones or, to avoid spurious socioeconomic consequences, be organized as MPAs networks; small scale MPAs may have local significant effects for fishermen, especially on their borders, but are not sufficient to change the whole dynamic of exploited stocks.

- A high priority in spatial design of MPAs should be assigned to the protection of essential habitats that play a crucial role in the life cycle of exploited resources. While spillover effects often appear limited, larvae dispersal and juvenile protection may have more significant effects at the stock scale, justifying some strict restrictions on all human activities, especially in spawning areas and nursery grounds.

- Short term effects on exploited resources can be expected from the reduction of overall fishing mortality induced by no-take zones. Full benefits from MPAs usually involve habitat restoration and require long term and uninterrupted protection.

- MPA objectives related to fish stocks and fisheries management do not necessarily require total closures. However, in order to be fully efficient and contribute to limit fishing pressure on certain stocks, MPAs should be integrated as part of wider integrated fisheries management plans. Such plans should particularly aim to avoid unplanned increases in the fishing pressure outside of protected areas.

- Enforcement of fisheries restrictions is of crucial importance and cannot be achieved without the implication of all stakeholders, including fishermens' representatives. Thus, participative decision-making appears essential for the success of MPAs, as an assurance of respect for restrictive measures.

More generally, even though governance-related aspects of MPAs are beyond the scope of the present paper, it should be noted that MPAs may also be efficient tools to test innovative management tools (new gears, new spatial or temporal access regulations, etc.) and to implement new relationships between stakeholders, thus contributing to improve dialogues and inclusive fisheries management.

Implementing increasingly larger MPAs is not a miracle solution for fisheries management, and many criticisms are now being raised (Kearney and Farebrother 2012). MPAs should be considered as a tool that can be efficiently implemented in an integrated framework for an ecosystem approach to fisheries management. MPAs should be included in a broad approach to spatial planning of all human activities at sea. They are also a way by which fisheries and conservation can be reconciled, ultimately contributing not only to the sustainability but also the long term social acceptance of the exploitation of living marine resources.

Acknowledgements. The authors would like to thank Philippe Gros (IFREMER) and several colleagues (especially Stéphanie Tachoires) from the French Agence des Aires Marines Protégées, in charge of public policies for the creation and management of marine protected areas, for fruitful discussions about the content of this paper.

\section{References}

Albouy C., Mouillot D., Rocklin D., Culioli J.M., Le Loch F., 2010, Simulation of the combined effects of artisanal and recreational fisheries on a Mediterranean MPA ecosystem using a trophic model. Mar. Ecol. Prog. Ser. 412, 207-221.

Alcala A.C., Russ G.R., 2006, No-take marine reserves and reef fisheries management in the Philippines: a new people power revolution. Ambio 35, 245-254.

Alcala A.C., Russ G.R., Maypa A.P., Calumpong H.P., 2005, A long term, spatially replicated experimental test of the effect of marine reserves on local fish yield. Can. J. Fish. Aquat. Sci. 62, 98-108. 
Anonyme, 2007, The Science of Marine Reserves (2nd edition, International version), 22p.

Ayling A.M., Choat J.H., 2008, Abundance patterns of reef sharks and predatory fishes on differently zoned reefs in the offshore Townsville region. Great Barrier Reef Marine Park Authority, Research Publication $\mathrm{n}^{\circ} 91$.

Barrett N.S., Edgar G.J., Buxton C.D., Haddon M., 2007, Changes in fish assemblages following ten years of protection in Tasmanian marine protected areas. J. Exp. Mar. Biol. Ecol. 345, 141-157.

Barrett N.S., Buxton C.D., Edgar G.J., 2009, Changes in invertebrate and macroalgal populations in Tasmanian marine reserves in the decade following protection. J. Exp. Mar. Biol. Ecol. 370, 104-119.

Beare D., Rijnsdorp A., Van Kooten T., Fock H., Schroeder A., Kloppman M., Witbaard R., Meesters E., Schulze T., Blaesbjerg M., Damm U., Quiriins F., 2010, Study for the Revision of the plaice box - Draft Final Report. C002/10.

Behrens M.D., Lafferty K.D., 2004, Effects of marine reserves and urchin disease on southern California rocky reef communities. Mar. Ecol. Prog. Ser. 279, 129-139.

Bergen L.K., Carr M.H., 2003, Establishing marine reserves, how can science best inform policy? Environment 45, 8-19.

Berkeley S.A., Chapman C., Sogard S.M., 2004, Maternal age as a determinant of larval growth and survival in a marine fish, Sebastes melanops. Ecology 85, 1258-1264.

Beukers-Stewart B.D., Mosley M.W.J., Brand A.R., 2003, Population dynamics and predictions in the Isle of Man fishery for great scallop (Pecten maximus). ICES J. Mar. Sci. 60, 224-242.

Beukers-Stewart B.D., Vause B.J., Mosley M.W.J., Rossetti H.L., Brand A.R., 2005, Benefits of closed area protection for a population of scallops. Mar. Ecol. Prog. Ser. 298, 189-204.

Blowes S., Connolly S., 2012, Risk spreading, connectivity, and optimal reserve spacing. Ecol. Appl. 22, 311-321.

Boncoeur J., 2004, Activités halieutiques et activités récréatives dans le cadre d'un espace à protéger: le cas du Parc National Marin d'Iroise. Rapport Final. Projet de recherche cofinancé par le Programme National d'Environnement Côtier, le programme "Espaces Protégés" du Ministère de l'Ecologie et du Développement Durable et la Région Bretagne. CEDEMIUEM/UBO, Ifremer, C3ED-UVSQ, Brest.

Brochier T., Ecoutin J.M., Tito de Morais L., Kaplan D., Laë R., 2013, A multi-agent ecosystem model for studying changes in a tropical estuarine fish assemblage within a marine protected area. Aquat. Living Resour. 26 doi.org/10.1051/alr/2012028.

Chateau O., Wantiez L., 2005, Comparaison de la structure des communautés de poissons coralliens entre une réserve marine et deux zones proches non protégées dans le Parc du Lagon Sud de Nouvelle-Calédonie. Cybium 29, 159-174.

Chateau O., Wantiez L., 2009, Movement patterns of four coral reef fish species in a fragmented habitat in New Caledonia: implications for the design of marine protected area networks. ICES J. Mar. Sci. 66, 50-55.

Claudet J., Osenberg C.W., Benedetti-Cecchi L., Domenici P., GarcíaCharton J.A., Pérez-Ruzafa A., Badalamenti F., Bayle-Sempere J., Brito A., Bulleri F., Culioli J.M., Dimech M., Falcón J.M., Guala I., Milazzo M., Sánchez-Meca J., Somerfield P.J., Stobart B., Vandeperre F., Valle C., Planes S., 2008, Marine reserves: size and age do matter. Ecol. Lett. 11, 481-489.

Colléter M., Gascuel D., Ecoutin J.M., De Morais L.T., 2012, Modelling trophic flows in ecosystems to assess the efficiency of Marine Protected Area (MPA), a case study on the coast of Senegal. Ecol. Model. 232, 1-13.
Criquet G., Garcia J., Lenfant P., Marechal J.P., Reynal L., 2008, Catches Description of Protected and Unprotected Areas in Martinique (Lesser Antilles). Proc. Gulf and Caribbean Fisheries Institute 60, 481-485.

David G., Léopold M., Dumas P.S., Ferraris J., Herrenschmidt J.B., Fontenelle G., 2010, Integrated coastal zone management perspectives to ensure the sustainability of coral reefs in New Caledonia. Mar. Pollut. Bull. 61, 323-334.

Edgar G.J., Barrett N.S., 1999, Effects of the declaration of marine reserves on Tasmanian reef fishes, invertebrates and plants. J. Exp. Mar. Biol. Ecol. 242, 107-144.

Edgar G.J., Barrett N.S., Morton A.J., 2004, Patterns of fish movement on eastern Tasmanian rocky reefs. Environm. Biol. Fish. 70, 273-284.

Edgar G.J., Stuart-Smith R.D., 2008, Ecological effects of marine protected areas on rocky reef communities - a continental-scale analysis. Mar. Ecol. Prog. Ser. 388, 51-62.

Fanshawe S., Vanblaricom G.R., Shelly A.A., 2003, Restored Top Carnivores as Detriments to the Performance of Marine Protected Areas Intended for Fishery Sustainability: a Case Study with Red Abalones and Sea Otters. Conserv. Biol. 17, 273-283.

FAO (Food and Agriculture Organisation), 2003, Aménagement des pêches. 2. L'approche écosystémique des pêches. FAO Directives techniques pour une pêche responsable, $\mathrm{n}^{\circ} 4$, suppl. 2, Rome, FAO.

FAO (Food and Agriculture Organisation), 2009. The State of World Fisheries and Aquaculture, 2008. FAO, Rome.

Ferraris J., Pelletier D., Kulbicki1 M., Chauvet C., 2005, Assessing the impact of removing reserve status on the Abore Reef fish assemblage in New Caledonia. Mar. Ecol. Prog. Ser. 292, 271-286.

Fogarty M.J., Murawski S.A., 1998, Large-scale disturbance and the structure of marine systems: fishery impacts on Georges Bank. Ecol. Appl. 8 suppl., S6-S22.

Forcada A., Valle C., Bonhomme P., Criquet G., Cadiou G., Lenfant P., Sánchez-Lizaso J., 2009, Effets of habitat on spillover from marine protected areas to artisanal fisheries. Mar. Ecol. Prog. Ser. $379,197-211$.

Francour P., Harmelin J.G., Pollard D., Sartoretto D., 2001, A review ok marine protected areas in the northwestern Mediterranean region: siting, usage, zonation and management. Aquatic Conservation: Mar. Freshw. Ecosyst. 11, 155-188.

Garcia S.M., Cochrane K.L., 2005, Ecosystem approach to fisheries: a review of implementation guidelines. ICES J. Mar. Sci. 62, 311-318.

Gell F.R., Roberts C.M., 2002, The Fishery Effects of Marine Reserves and Fishery Closures. WWF-US, 1250 24th Street, NW, Washington, DC 20037.

Gell F.R., Roberts C.M., 2003, Benefits beyond boundaries: the fishery effects of marine reserves. Trends Ecol. Evol. 18, 448-455.

Grift R.E., Tulp I., Clarke L., Damm U., McLay A., Reeves S., Vigneau J., Weber W., 2004, Assessment of the ecological effects of the Plaice Box. Report of the European Commission Expert Working Group to evaluate the Shetland and Plaice boxes, Brussels.

Grüss A, Kaplan D.M., Guénette S, Roberts C.M., Botsford L.W., 2011a, Consequences of adult and juvenile movement for marine protected areas. Biol. Conserv. 144, 692-702.

Grüss A., Kaplan D., Hart D.R., 2011b, Relative Impacts of Adult Movement, Larval Dispersal and Harvester Movement on the Effectiveness of Reserve Networks. PLoS One 6, e19960.

Guénette S., Pitcher T.J., Walter C.J., 2000, The potential of marine reserves for the management of northern cod in Newfoundland. Essential fish habitat and marine reserves. Bull. Mar. Sci. 66, 831-852. 
Guidetti P., 2006, Marine reserves reestablish lost predatory interactions and cause community changes in Rocky Reefs. Ecol. Appl. $16,963-976$.

Guidetti P., Notarbartolo-Di-Sciara G., Agardy T., 2013, Integrating pelagic and coastal MPAs into large scale ecosystem-wide management. Aquat. Conserv. Mar. Freshw. Ecosyst. 23, 179-182.

Guillemot N., Leopold M., Cuif M., Chabanet P., 2009, Characterization and management of informal fisheries confronted with socio-economic changes in New Caledonia (South Pacific). Fish. Res. 98, 51-61.

Halpern B.S., 2003, The impact of marine reserves: do reserves work and does reserve size matter? Ecol. Appl. 13, suppl. S117-S137.

Hamilton S.L., Caselle J.E., Malone D.P., Carr M.H., 2010, Incorporating biogeography into evaluations of the Channel Islands marine reserve network. Proc. Natl. Acad. Sci. USA 107, $18272-18277$.

Hannesson R., 1998, Marine Reserves: What would they accomplish? Mar. Resour. Econ. 13, 159-170.

Harmelin-Vivien M., Le Diréach L. Bayle-Sempere J., Charbonnel E., García-Charton J.A., Ody .D., Pérez-Ruzafa A., Reñones O., Sánchez-Jerez P., Valle C., 2008, Gradients of abundance and biomass across reserve boundaries in six Mediterranean marine protected areas: evidence of fish spillover? Biol. Conserv. 141, $1829-1839$

Harrison H., Williamson D.H., Evans R., Almany G., Thorrold S., Russ G., Feldheim K., Van Herwerden L., Planes S., Srinivasan M., Berumen M., Jones G., 2012, Larval export from marine reserves and the recruitment benefit for fish and fisheries. Curr. Biol. 22, 1023-1028.

Hart D.R., 2006, When do marine reserves increase fishery yields? Can. J. Fish. Aquat. Sci. 63, 1445-1449.

Hart D.R., Rago P.J., 2006, Long-term dynamics of US Atlantic sea scallop Placopecten magellanicus populations. N. Am. J. Fish. Manage. 26, 490-501.

Hilborn R., Stokes K., Maguire J.J., Smith T., Botsford L.W., Mangel M., Orensanz J., Parma A., Rice J., Bell J., Cochrane K.L., Garcia S., Hall S.J., Kirkwood G.P., Sainsbury K., Stefansson G., Walters C., 2004, When can marine reserves improve fisheries management? Ocean Coast. Manage. 47, 197-205.

Holland D., 2000, A bioeconomic model of sanctuaries on Georges Bank. Can. J. Fish. Aquat. Sci. 57, 1307-1319.

ICES, 2007, Report of the Working Group on the Assessment of Southern Shelf Demersal Stock (WGSSDS) 25 June-7 July 2007, ICES Headquarters, Copenhagen, ICES CM 2007/ACFM:28.

Imeson R.J., Van Den Bergh J.C.J.M., 2006, Policy failure and stakeholder dissatisfaction in complex ecosystem management: The case on the Dutch Wadden Sea shell fishery. Ecol. Econ. 56, 488-507.

Jennings S, Rice J., 2011, Towards an ecosystem approach to fisheries in Europe: a perspective on existing progress and future directions. Fish Fish. 12, 125-137.

Jollit I., Léopold M., Guillemot N., David G., Chabanet P., Lebigre J.M., Ferraris J., 2010, Geographical aspects of informal reef fishery systems in New Caledonia. Mar. Pollut. Bull. 61, 585-597.

Kaplan D.M., 2009, Fish life histories and marine protected areas: an odd couple? Mar. Ecol. Prog. Ser. 377, 213-225.

Kaplan D.M., Botsford L.W., Jorgensen S., 2006, Dispersal per recruit: an efficient method for assessing sustainability in marine reserve networks. Ecol. Appl. 16, 2248-2263.

Kearney R., Farebrother G., 2012, Marine management: Expand Australia's sustainable fisheries. Nature 482, 162.

Kelleher G., 1999, Guidelines for marine protected areas. IUCN, Gland, Switzerland and Cambridge.
Lester S.E., Halpern B.S., Grorud-Colvert K., Lubchenco J., Ruttenberg B.I., Gaines S.D., Airamé S., Warner R.R., 2009, Biological effects within no-take marine reserves: a global synthesis. Mar. Ecol. Prog. Ser. 384, 33-46.

Ling S., Johnson C., 2012, Marine reserves reduce risk of climate driven phase shift by reinstating size- and habitat-specific trophic interactions. Ecol. Appl. 22, 1232-1245.

Little L.R., Punt A.E., Mapstone B.D., Begg G.A., Goldman B., Ellis N., 2009, Different responses to area closures and effort controls for sedentary and migratory harvested species in a multispecies coral reef linefishery. ICES J. Mar. Sci. 66, 1931-1941.

McCook L.J., Ayling T., Cappo M., Choat J.H., Evans R.D., De Freitas D.M., Heupel M., Hughes T.P., Jones G.P., Mapstone B., Marsh H., Mills M., Molloy F.J., Pitcher C.R., Pressey R.L., Russ G.R., Sutton S., Sweatman H., Tobin R., Wachenfeld D.R., Williamson D.H., 2010, Adaptative management of the Great Barrier Reef : A globally significant demonstration of the benefits of networks of marine reserves. Proc. Natl. Acad. Sci. 107, $18278-18285$

Maury O., Gascuel D., 1999, SHADYS (simulateur halieutique de dynamiques spatiales), a GIS based mumerical model of fisheries. Example application: the study of a marine protected area. Application à l'étude d'une réserve marine. Aquat. Living Resour. 12, 77-88.

MEA (Millennium Ecosystem Assessment), 2005. Ecosystems and human well-being: synthesis. Island Press, Washington, DC.

Moffitt E.A., Botsford L.W., Kaplan D.M., O’Farrell M.R., 2009, Marine reserve networks for species that move within a home range. Ecol. Appl. 19, 1835-1847.

Murawski S.A., Brown R., Lai H.L., Rago P.J., Hendrickson L., 2000, Large-scale closed areas as a fisheries management tool in temperate marine systems: the Georges Bank experience. Bull. Mar. Sci. 66, 775-798.

Murawski S.A., Wigley S.E., Fogarty M.J., Rago P.J., Mountain D.G., 2005, Effort distribution and catch patterns adjacent to temperate MPAs. ICES J. Mar. Sci. 62, 1150-1167.

Nagelkerten I., Grol M., Mumby P., 2012, Effects of marine reserves versus nursery habitat availability on structure of reef fish communities. PLos One, 7, e36906.

Neigel J.E., 2003, Species-area relationships and marine conservation. Ecol. Appl. 13 suppl S138-S145.

Pauly D., Alder J., Bennett E., Christensen V., Tyedmers P., Watson R., 2003, The future of fisheries. Science 302, 1359-1361.

Pastoors M.A., Rijnsdorp A.D., Van Beek F.A., 2000, Effects of partially closed area in the North Sea ("Plaice box") on stock development of plaice. ICES J. Mar. Sci. 57, 1014-1022.

Pelletier D., Magal P., 1996, Dynamics of a migratory population under different fishing effort allocation schemes in time and space. Can. J. Fish. Aquat. Sci. 53, 1186-1199.

Pérez-Ruzafa A., González-Wangüemert M., Lenfant P., Marcos C., García-Charton J.A., 2006, Effects of fishing protection on the genetic structure of fish populations. Biol. Conserv. 129, 244-255.

Pitchford J.W., Codling E.A., Psarra D., 2007, Uncertainty and sustainability in fisheries and the benefit of marine protected areas. Ecol. Model. 207, 286-292.

Planes S., García-Charton J.A., Marcos C., Pérez-Ruzafa A., 2008, Ecological effects of Atlanto-Mediterranean Marine Protected Areas in the European Union. EMPAFISH Project, Booklet $\mathrm{n}^{\circ} 1$.

Preuss B., Pelletier D., Wantiez L., Letourneur Y., Sarramegna S., Kulbicki M., Galzin R., Ferraris J., 2009, Considering multiplespecies attributes to understand better the effects of successive changes in protection status on a coral reef fish assemblage. ICES J. Mar. Sci. 66, 170-179. 
Rice J., Moksness E., Attwood C., Brown S., Dahle G, Gjerde K.M., Grefsrud E.S., Kenchington R., Kleiven A.R., McConney P., Ngoile M.A.K., Næsje T.F., Olsen E., Olsen E.M., Sanders J., Sharma C, Vestergaardm O., Westlund L., 2012. The role of MPAs in reconciling fisheries management with conservation of biological diversity. Ocean Coast. Manage. 69, 217-230.

Roberts C.M., Bohnsack J.A., Gell F., Hawkins J.P., Goodridge R., 2001, Effects of marine reserves on adjacent fisheries. Science 294, 1920-1923.

Roberts C.M., Hawkins J.P., 2000, Fully-protected marine reserves: a guide. WWF Endangered Seas Campaign, and Environment Department, University of York, York, UK.

Roberts C.M., Hawkins J.P., Gell F.R., 2005, The role of marine reserves in achieving sustainable fisheries. Phil. Trans. R. Soc. B 360, 123-132.

Roberts C.M., Hawkins, J.P., 2012, Establishment of fish stock recovery areas. Report of the European Parliament, Directorate General for Internal Policies, Policy Dep. B: structural and cohesion policies, Fisheries, IP/B/PECH/IC/2012-053.

Russ G.R., Alcala A.C., 1996, Do marine reserves export adult fish biomass? Evidence from Apo Island, Central Philippines. Mar. Ecol. Prog. Ser. 132, 1-9.

Russ G.R., Alcala A.C., Maypa A.P., 2003, Spillover from marine reserves: the case of Naso vlamingii at Apo Island, the Philippines. Mar. Ecol. Prog. Ser. 264, 15-20.

Russ G.R., Cheal A.J., Dolman A.M., Emslie M.J., Evans R.D., Miller I., Sweatman H., Williamson D.H., 2008, Rapid increase in fish numbers follows creation of world's largest marine reserve network. Curr. Biol. 18, R514-R515.

Saintilan N., Mazumber D., Cranney K., 2008, Changes to fish assemblages visiting estuarine wetlands following the closure of commercial fishing in Botany Bay, Australia. Aquat. Ecosyst. Health $11,441-9$.

Sale P.F., Cowen R.K., Danilowicz B.S., Jones G.P., Kritzer J.P., Lindeman K.C., Planes S., Polunin N., Russ G.R., Sadovy Y.J., Steneck S., 2005, Critical science gaps impede use of no-take fishery reserves. Trends Ecol. Evol. 20, 74-80.

Sanchirico J.N., Cochran K.A., Emerson P.M., 2002, Marine Protected Areas: economic and social implications. Resources for the future, Discuss. Pap. 2-26.

Sethi S.A., Hilborn R., 2008, Interactions between poaching and management policy affect marine reserves as conservation tools. Biol. Conserv. 141, 506-516.

Shanks A.L., Grantham B.A., Carr M.H., 2003, Propagule dispersal distance and the size and spacing of marine reserves. Ecol. Appl. 13, suppl S159-S169.

Shears N.T., Babcock R.C., 2003, Continuing trophic cascade effects after 25 years of no-take marine reserve protection. Mar. Ecol. Prog. Ser. 246, 1-16.

Shears N., Babcock R., Salomon A., 2008, Context-dependent effects of fishing: variation in trophic cascades across environmental gradients. Ecol. Appl. 18, 1860-1873.
Scholz A., Bonzon K., Fujita R., Benjamin N., Woodling N., Black P., Steinback C., 2004, Participatory socioeconomic analysis: drawing on fishermen's knowledge for marine protected area planning in California, Mar. Policy 28, 335-349.

Sweeting C.J., Polunin N.V.C., 2005, Marine protected areas for management of temperate north Atlantic fisheries. University of Newcastle upon Tyne, Dep. Environm. Food Rural Affairs Report.

Tetreault I., Ambrose R.F., 2007, Temperate marine reserves enhance targeted but not untargeted fishes in multiple no-take MPAs. Ecol. Appl. 17, 2251-2267.

Tian R.C., Chen C., Stokesbury K.D.E., Rothschild B.J., Cowles G.W., Xu Q., Hu S., Harris B.P., Marino II M.C., 2009, Dispersal and settlement of sea scallop larvae spawned in the fishery closed areas on Georges Bank. ICES J. Mar. Sci. 66, 1-10.

Uriarte A., Alvarez P., Iversen S., Molloy J., Villamor B., Martíns M.M., Myklevol S., 2001, Spatial pattern of migration and recruitment of northeast Atlantic mackerel. ICES Annual Science Conference, 26-28 Sept. 2001, ICES CM 2001/O: 17.

Valls A., Gascuel D., Guénette S., Francour P., 2012, Modeling trophic interactions to assess the potential effects of a marine protected area: case study in the NW Mediterranean Sea. Mar. Ecol. Prog. Ser. 456, 201-214.

Van de Wolfshaar K., HilleRisLambers R., Gardmark A., 2011, Effect of habitat productivity and exploitation on populations with complex life cycles. Mar. Ecol. Prog. Ser. 438, 175-184.

Vandeperre F., Higgins R.M, Sánchez-Meca J., Maynou F., Goñi R., Martín-Sosa P., Pérez-Ruzafa A., Afonso P., Bertocci I., Crec'hriou R., D'Anna G., Dimech M., Dorta C., Esparza O., Falcón J.M., Forcada A., Guala I., Le Direach L., Marcos C., Ojeda-Martínez C., Pipitone C., Schembri P.J., Stelzenmüller V., Stobart B., Santos R.S., 2010, Effects of no-take area size and age of marine protected areas on fisheries yields: a meta-analytical approach. Fish Fish. 12, 412-426.

Verhulst S., Oosterbeek K, Rutten A.L., Ens B.J., 2004, Shellfish fishery severely reduces condition and survival of oystercatchers despite creation of large marine protected areas. Ecol. Soc. 9, 17

Wantiez L., Thollot P., Kulbicki M., 1997, Effects of marine reserves on coral reef fish communities from five islands in New Caledonia. Coral Reefs 16, 215-225.

Worm B., Barbier E.B., Beaumont N., Duffy J.E., Folke C., Halpern B.S., Jackson J., Lotze H.K., Micheli F., Palumbi S.R., Sala E., Selkoe K.A., Stachowicz J.J., Watson R., 2006, Impacts of biodiversity loss on ocean ecosystem services. Science 314, 787-790.

Worm B., Hilborn R., Baum J., Branch T.A., Collie J.S., Costello C., Fogarty M.J., Fulton E, Hutchings J.A., Jennings S., Jensen O.P., Lotze H.K., Mace P.M., McClanahan T.R., Minto C., Palumbi S.R., Parma A.M., Ricard D., Rosenberg A.A., Watson R., Zeller D., 2009, Rebuilding global fisheries. Science 325, 578-584. 